Volume: 11 Issue: 1 Year: 2014

\title{
Factors of felon disfranchisement in the United States
}

\author{
Bahadır Şahin ${ }^{1}$ \\ İsmail Şahin ${ }^{2}$
}

\begin{abstract}
There is no doubt that participating in election process is a very basic right for citizens living in democratic society regardless of their background, race, and socio-economic status. In the U.S., states disfranchise a large number of citizens from election process because of their felony convictions. The states have different laws and policy implementations pertaining to felon disfranchisement. It is suggested that these policy differences result from the states' different characteristics such as political cultures, demographic features, and crime rates. Using an interdisciplinary approach to this policy issue, this study aims to empirically investigate the relationship between felon disfranchisement and states attributes such as political culture and criminal justice facts. First, the results of this study suggest that traditionalistic southern states have a higher rate of disfranchisement than other states, which supports the assumption that political culture has impact on felon disfranchisement. Second, political climate of a region is likely to affect disfranchisement of people more than criminal justice facts.
\end{abstract}

Keywords: Felon Disfranchisement, Political Culture, Criminal Justice, Political Climate, Felony.

\section{Introduction}

It is theoretically considered that criminal justice policies are made and implemented to deal with crime issues. However, there are some government policies regarding criminal justice issues that actually result in significant political consequences. In this sense, it can be suggested that felon disfranchisement is one of the most remarkable examples for these kinds of policies. Even though the main rationale behind the policy of felon disfranchisement is to punish the ones who have committed felony crimes, it is obvious that this policy tool have been widely used as a tool to restrict the right of voting (Manza \& Uggen, 2006). Disfranchisement of these people from participation in democratic elections is considered as a significant threat to the democracy in the U.S. (Manza \& Uggen, 2006).

\footnotetext{
${ }^{1}$ Ph.D., Istanbul Police Department. bahadirkhan@gmail.com

2 Ph.D., Director of TADOC (Turkish International Academy against Drugs and Organized Crime). Turkish National Police.sahini38@hotmail.com
} 
Şahin, B., \& Şahin, İ. (2014). Factors of felon disfranchisement in the United States. International Journal of Human Sciences, 11(1), 778-793. doi: $10.14687 /$ ijhs.v11i1.2773

According to Keyssar (2000), "the right to vote has never been formally enshrined in the nation's constitutional order... the Bill of Rights guaranteed Americans' freedom of speech and the right to bear arms, but it did not guarantee the right to participate in elections" (p. 317). The people in the U.S. still have no right to vote guaranteed by the U.S. constitution. States retains the right to decide who is eligible to vote; however, they have to comply with some federal principles (Keyssar, 2000). Discrimination in voting on the basis of race, sex, or age (for citizens 18 or over) is prohibited by $15^{\text {th }}, 19^{\text {th }}, 24^{\text {th }}$, and $26^{\text {th }}$ Amendments to the U.S. Constitution. However, this does not mean that the constitution establishes a universal right to vote. Constitutionally guaranteed right to vote is considered as the very foundation of representative democratic systems. In more than135 countries in the world, citizens' right to vote is explicitly guaranteed by the constitutions (Raskin, 2001). In the U. S. today, the number of citizens denied the right to vote due to felony conviction is remarkably high. Furthermore, political scientists argue that felon disfranchisement also leads to racial discrimination in terms of being represented in democratic system since the felon population is disproportionately African American.

As explained in the following sections in the article, the states have different laws and policy implementations pertaining to felon disfranchisement. It is suggested that these policy differences result from the states' different characteristics such as political cultures, demographic features, and crime rates. To be able to adequately investigate the relationship between felon disfranchisement and states attributes, interdisciplinary approach to this policy issue is essential, which means that there is a need of the appropriate combination of knowledge from different fields and specialties (Ausburg, 2006). Complex policy issues such as felon disfranchisement require interdisciplinary approach since the conventional knowledge in a particular field is sometimes unable to provide adequate explanation and solution.

Disfranchisement of criminals has been a political issue in the U.S. more than it has become a criminal justice issue. Although the research did not clearly indicate the state's political differences on this problem (James, 1988), the national research data suggested a significant disfranchisement in the U.S. related to racial discrimination (Hero \& Tolbert, 1996). Political culture studies suggested that the states in the U.S. have different political perspectives based on the geography they belong to (Elazar, 1974). In this study, forty eight adjacent states are examined in terms of the political culture and criminal justice facts on disfranchisement of criminals.

Political culture represents the moral values of a population. Hero and Tolbert (1996) redefine Elazar's classifications in terms of the diversity of homogeneous populations. Same-race or same-religion populations form a homogenic society and a homogenic state while different-race or different-religious culture populations form heterogenic states. Besides these two types, there are 
Şahin, B., \& Şahin, İ. (2014). Factors of felon disfranchisement in the United States. International Journal of Human Sciences, 11(1), 778-793. doi: $10.14687 /$ ijhs.v11i1.2773

some other states that have both types of societies. These states are classified as bifurcated by Hero and Tolbert (1996). Homogenic states (one-culture dominant) are likely to have moralistic political culture. Heterogenic states (several-culture dominant) generally reflect an individualistic culture, while bifurcated states (greater minority diversity) keep the traditionalistic culture. Elazar's findings and measurement scale of political culture was heavily criticized by some scholars for being imaginative and inconsistent (Sharkansky, 1969; Lieske, 1993). Sharkansky (1969) tested Elazar's scale and indicated the uncorrelated facts in terms of different social-economical variables. Lieske (1993) used the inconsistencies that the critics found in Elazar's findings and built a sub-regional map based on various factors affecting political culture. Later, Lieske (2008) created a typology similar to Elazar's political culture scale based on his sub-regional mapping. The typology included different sub-cultural variables than Elazar's scale. However, Lieske (2008) categorized those variables to create three different state-scales which are MIPBS (M-Moralistic; I-Individualistic; PPluralistic; B-Bifurcated; S-Separatist) and MIPT (M-Moralistic; I-Individualistic; P-Pluralistic; TTraditionalistic) and MIT (M-Moralistic; I-Individualistic; T-Traditionalistic) as shown in Table 1. This study also aims to suggest the best political culture predictor scale in terms of rate of disfranchisement.

\section{Literature Review}

Russ (1934) called the Reconstruction period as Republicanization period. The victors of the war applied the minority (most frequently African-Americans) enfranchisement to the southern states. The southern states had applied slavery to a great extent; the economy and agriculture of the South utilized slaves as an important labor power. After the war, the white supremacy continued in different forms such as cruel punishments for minorities and disfranchisement. Criminal sanctions such as lynching in the southern states were based on the color of the criminals until the 1920s (Wasserman, 1977). The white supremacists were discussed and criticized for being from different social-economical levels; however, the tools to restrain the minority from voting and being voted remained the same (Perman, 2001, p. 3). Racial discrimination in the southern states affected social policies and even the criminal justice systems. Corzine, Creech, \& Corzine (1983) argue that the minority population effect on criminal justice issues is only related to the political culture of the state. Their study could not find a relationship between percentage of the African-American populations and rate of public lynching of black people. It was about the political culture of the geography (Corzine, Creech, \& Corzine, 1983).

When the Thirty Ninth Congress agreed on a proposal for Fourteenth Amendment that brings equality to the former slaves in voting rights in 1866, the South did not accept this federal ruling easily. North Carolina, Louisiana, South Carolina, Virginia, Texas, and Kentucky States 
Şahin, B., \& Şahin, İ. (2014). Factors of felon disfranchisement in the United States. International Journal of Human Sciences, 11(1), 778-793. doi: $10.14687 /$ ijhs.v11i1.2773

accepted the Amendment only after rejecting it firstly in 1866. The rebellion spirit was still the same in the South therefore they were forced to do the constitutional changes by the conquerors (James, 1956). Southern states' critic was that they were not asked about the changes in constitutions; however, they did not ask the human beings that they used as slaves either.

\subsection{The Voting Rights Act (VRA)}

Until the VRA enacted, the suffrage of minorities have remained as a problem in different states. The Act firstly was designed only for African-Americans, but in 1975, minorities such as Hispanics, Asians and others were included in the scope of the act. VRA also was enacted because of southern violence against minorities. The U.S. Commission on Civil Rights reported that only $35.5 \%$ of African Americans of voting age in the southern states were registered to vote compared to $73.4 \%$ of voting-age whites in the U.S. The most discriminative state was Mississippi which only allowed $6.7 \%$ of African-American population to vote (Engstrom, 1994). VRA put an end to different implications such as literacy tests that the southern state officials used to discriminate minorities. VRA was enacted and mandated so similar to the reconstruction that it was called the “second reconstruction” (Behrens, Uggen, \& Manza, 2003).

Nevertheless, VRA was not successful to stop minority discrimination all the way. Criminal sanctions were held against the minorities harsher than they were hold against whites. Zeisel (1981) presents specific examples from Florida to show how these discriminative sanctions were utilized against African-American people. The study found out that the African-American criminals were more likely to get a death penalty than white criminals in same conditions. Moreover, if the victim was white, then the suspect was more likely to get death penalty than in a situation where the victim was African-American in Florida (Zeisel, 1981).

\subsection{Felon Disfranchisement}

In the 2004 elections, five million people could not vote because of a prior felony conviction. As discussed in the previous part, political culture is highly effective on disfranchisement policies as well (Behrens, 2004). These policies generally affect the minorities even though the federal rulings make it clear that discrimination on suffrage based on race, sex, or wealth is illegal. Forty eight U.S. states apply disfranchisement to the incarcerated people in some ways. Vermont and Maine are the only two states that do not punish those who are imprisoned or exfelons with disfranchisement presently. By 1850, one third (eleven out of thirty two) of the states were applying disfranchisement to felons and/or ex-felons. However, the Civil War changed the perceptions and policies as discussed above, which resulted in twenty eight disfranchising-states out of thirty eight. It was not only the increase in disfranchisement rate among the states but also the 
Şahin, B., \& Şahin, İ. (2014). Factors of felon disfranchisement in the United States. International Journal of Human Sciences, 11(1), 778-793. doi: $10.14687 /$ ijhs.v11i1.2773

extent of felony definition. Even small felonies resulted in disfranchisement after the Civil War (Behrens, 2004).

Felon disfranchisement policies change the result of elections in the southern states dramatically. By January 2008, of the 1,013 state legislators in Virginia, Kentucky, Florida, North Carolina, Mississippi, and Louisiana states, only 17\% were African American and $0.29 \%$ were Latino, despite the fact that African American and Latino populations were $24.8 \%$ and $4.3 \%$, respectively, across named states (Levitas \& Cox, 2008). There are other reasons such as education, socio-economic status that produce underrepresentation of minorities in elected personnel; nonetheless, many scholars argued that even the race-neutral language of the amendments could not prevent discriminatory actions against minority suffrage (Behrens, Uggen, \& Manza, 2003).

Even the white legislators have seen the disfranchisement of criminals as a tool that prevents minorities (specifically African-Americans) from voting. McMillan (1955) quoted from a speaker in an Alabama Supreme Court case in 1901 that indicated the effect of political culture on policy making against minorities. John Field Bunting -the member of an all-white court committeeintroduced the disfranchisement law as a legal instrument that will abolish African-American suffrage. Bunting added that "the crime of wife-beating alone would disqualify sixty percent of the Negroes" (McMillan, 1955, p. 275). Since the minorities are generally believed to be voting for Democrat Party recently, the proponents of criminal disfranchisement are generally from Republican Party. Behrens et al. (2003) give different examples from a U.S. senate meeting discussing a federal bill that aims to get rid of felon disfranchisement throughout the U.S. Two different republican senators from Kentucky and Alabama States opposed the bill since it would bring social disorder and since enfranchisement of criminals is against traditions. These examples show that the political culture in some states may result in some legislation against minority rights including felon disfranchisement. The most eye-catching example for disfranchisement's effect on public policy was the presidential elections in the U.S. in 2000. Florida State legally banned more than 500,000 people from voting because of alleged prior felonies where the president was elected only for 567 extra votes (Rapoport, 2001).

\section{Research Questions}

The study offers three basic assumptions. Firstly, the effect of geography on public policies will be examined. It will be tested if the rate of disfranchisement in a state is affected by the region of the state. The census regions (Northwestern, Southern, Midwestern and Western states) are compared in terms of rate of disfranchisement and other criminal justice variables that are considered to have an impact on disfranchisement rates. The assumption is that the southern states have statistically higher 
Şahin, B., \& Şahin, İ. (2014). Factors of felon disfranchisement in the United States. International Journal of Human Sciences, 11(1), 778-793. doi: $10.14687 /$ ijhs.v11i1.2773

numbers of disfranchisement rate than other states do. This assumption is not about the political culture, it is purely based on the geographical region of a state.

The second and more specific assumption is about the political culture and rate of disfranchisement. The study supposes that the political culture of a state has an important impact on the disfranchisement policies. More specifically, it will be considered that the traditionalistic states have a higher rate of disfranchisement than moralistic and individualistic states holding all other variables constant. It is argued in the literature that the southern states have a higher rate of disfranchisement as discussed above. Since the southern states are generally traditionalistic (Table 1), the study made this second assumption about political culture. This assumption also includes the insignificant effect of criminal justice variables over political culture.

The third and final assumption is that the political culture scale that Elazar built is less successful than the one Lieske built later. The study presupposes that the Lieske's political culture groups are more successful than Elazar's scale. Since Lieske's findings are more updated, it is considered that the prediction power of Lieske's scales is stronger than Elazar's. Elazar's scale is highly affected by the minority diversity; therefore changed demographics of the U.S. since Elazar built his scale in 1984 will decrease the chance of predictability of his scale. For the same reason, Lieski's updated scales will be more successful.

\section{Methodology}

The relationship between political culture and discriminating policies are statistically significant according to Hero and Tolbert (1996) as well. They used the scale Elazar (1984) created to compare states in the U.S. based on geographical places and social values. The same scale is utilized in this study to seek for a relationship between political culture and felon disfranchisement. Lieske's (2008) new political culture classifications are compared to that of Elazar's. The study utilizes ANOVA results of each classification to obtain the group differences firstly. Then, regression analysis seeks for a relationship between felon disfranchisement and classifications in the literature.

Minority diversity is another variable Elazar (1984) argued to have an impact on political culture. The study also seeks for a correlation between minority diversity rate and disfranchisement of criminals (Table 2). Minority diversity is an important factor affecting the political culture since the population means political power. The lower the minority diversity values the states have in Table 1, the less minority population they have. Greater minority populations usually change the political culture into a more traditionalistic one. The southern states generally have greater minority populations than the other states in this study, which can be said to be an important factor for the political culture. 
Table 1 Regions, Divisions of States and Political Culture

\begin{tabular}{|c|c|c|c|c|c|c|}
\hline State & Region a & Division $^{a}$ & $\begin{array}{l}\text { Pol. Culture } \\
\text { Elazar b }\end{array}$ & $\begin{array}{l}\text { Pol. Culture } \\
\text { Lieske 5Fold }{ }^{\mathrm{b}}\end{array}$ & $\begin{array}{l}\text { Pol. Culture } \\
\text { Lieske 4Fold }\end{array}$ & $\begin{array}{l}\text { Pol. Culture } \\
\text { Lieske 3Fold }{ }^{\mathrm{b}}\end{array}$ \\
\hline Alabama & South & East South Central & TI & $\overline{\mathrm{BP}}$ & $\overline{\mathrm{TP}}$ & TI \\
\hline Arizona & West & Mountain & TM & PS & PT & IT \\
\hline Arkansas & South & West South Central & TI & $\mathrm{BP}$ & TP & TI \\
\hline California & West & Pacific & MI & PS & PT & IT \\
\hline Colorado & West & Mountain & M & $\mathrm{P}$ & $\mathrm{P}$ & I \\
\hline Connecticut & Northeast & New England & IM & PM & PM & IM \\
\hline Delaware & South & South Atlantic & I & $\mathrm{P}$ & $\mathrm{P}$ & I \\
\hline Florida & South & South Atlantic & TI & PI & PI & I \\
\hline Georgia & South & South Atlantic & TI & $\mathrm{BP}$ & TP & TI \\
\hline Idaho & West & Mountain & MI & PM & PM & IM \\
\hline Illinois & Midwest & East North Central & IM & PI & PI & I \\
\hline Indiana & Midwest & East North Central & I & IP & IP & I \\
\hline Iowa & Midwest & West North Central & MI & IP & IP & I \\
\hline Kansas & Midwest & West North Central & MI & PI & PI & I \\
\hline Kentucky & South & East South Central & TI & BP & $\mathrm{TP}$ & IT \\
\hline Louisiana & South & West South Central & TI & BM & TM & TM \\
\hline Maine & Northeast & New England & M & MP & MP & MI \\
\hline Maryland & South & South Atlantic & I & $\mathrm{P}$ & $\mathrm{P}$ & I \\
\hline Massachusetts & Northeast & New England & IM & MP & MP & MI \\
\hline Michigan & Midwest & East North Central & M & IP & IP & I \\
\hline Minnesota & Midwest & West North Central & M & MP & MP & MI \\
\hline Mississippi & South & East South Central & $\mathrm{T}$ & $\mathrm{BP}$ & $\mathrm{TP}$ & TI \\
\hline Missouri & Midwest & West North Central & IT & $\mathrm{P}$ & $\mathrm{P}$ & IT \\
\hline Montana & West & Mountain & MI & $\mathrm{P}$ & $\mathrm{P}$ & I \\
\hline Nebraska & Midwest & West North Central & IM & PI & PI & I \\
\hline Nevada & West & Mountain & I & $\mathrm{P}$ & $\mathrm{P}$ & I \\
\hline N. Hampshire & Northeast & New England & MI & M & M & M \\
\hline New Jersey & Northeast & Middle Atlantic & I & PI & PI & I \\
\hline New Mexico & West & Mountain & TI & S & $\mathrm{T}$ & $\mathrm{T}$ \\
\hline New York & Northeast & Middle Atlantic & $\mathrm{IM}$ & PI & PI & I \\
\hline N. Carolina & South & South Atlantic & TM & BP & TP & TI \\
\hline North Dakota & Midwest & West North Central & M & M & M & M \\
\hline Ohio & Midwest & East North Central & $\mathrm{IM}$ & IP & IP & I \\
\hline Oklahoma & South & West South Central & TI & PB & PT & IT \\
\hline Oregon & West & Pacific & M & $\mathrm{P}$ & $\mathrm{P}$ & I \\
\hline Pennsylvania & Northeast & Middle Atlantic & I & IP & IP & I \\
\hline Rhode Island & Northeast & New England & $\mathrm{IM}$ & M & M & M \\
\hline S. Carolina & South & South Atlantic & $\mathrm{T}$ & $\mathrm{BP}$ & $\mathrm{TP}$ & $\mathrm{TI}$ \\
\hline South Dakota & Midwest & West North Central & MI & MP & MP & MI \\
\hline Tennessee & South & East South Central & $\mathrm{T}$ & $\mathrm{BP}$ & $\mathrm{TP}$ & TI \\
\hline Texas & South & West South Central & TI & PS & PT & IT \\
\hline Utah & West & Mountain & M & M & M & M \\
\hline
\end{tabular}


Şahin, B., \& Şahin, İ. (2014). Factors of felon disfranchisement in the United States. International Journal of Human Sciences, 11(1), 778-793. doi: $10.14687 /$ ijhs.v11i1.2773

\begin{tabular}{|c|c|c|c|c|c|c|}
\hline Vermont & Northeast & New England & $\mathrm{M}$ & $\mathrm{M}$ & $\mathrm{M}$ & M \\
\hline Virginia & South & South Atlantic & $\mathrm{T}$ & PB & PT & IT \\
\hline Washington & West & Pacific & MI & $\mathrm{P}$ & $\mathrm{P}$ & I \\
\hline West Virginia & South & South Atlantic & $\mathrm{TI}$ & IP & IP & I \\
\hline Wisconsin & Midwest & East North Central & $\mathrm{M}$ & IM & IM & $\mathrm{IM}$ \\
\hline Wyoming & West & Mountain & IM & $\mathrm{P}$ & $\mathrm{P}$ & I \\
\hline
\end{tabular}

MIPBS: M-Moralistic; I-Individualistic; P-Pluralistic; B-Bifurcated; S-Separatist

MIPT: M-Moralistic; I-Individualistic; P-Pluralistic; T-Traditionalistic

MIT: M-Moralistic; I-Individualistic; T-Traditionalistic

a Population Division, 2008

${ }^{\mathrm{b}}$ Lieske, 2008

Elazar's (1984) minority diversity was from 1984. There had been great immigration movements from that time that changed demographics dramatically; therefore, the study uses Census data from the year 2007 related to the percentage of minorities in a state. The study also includes important criminal justice variables in the selected states. It is considered that the felon disfranchisement can be affected by incarceration rate and/or violent crime rates in those states apart from political culture as suggested by the literature above. A significant relationship among those variable is expected to show that political culture or geography may not be the only independent factor on felon disfranchisement. Table 2 indicates the data on selected variables. The statistics are obtained from U.S. Department of Justice (USDOJ (a), and USDOJ (b), 2008) and the Sentencing Project website (2008).

Table 2 Criminal Justice Variables State by State

\begin{tabular}{lcccc}
\hline State & Rate of disenfranchisement & $\begin{array}{l}\text { Incarceration } \\
\text { Rate }^{\mathbf{b}}\end{array}$ & $\begin{array}{l}\text { Violent Crime } \\
\text { Rate }^{\mathbf{c}}\end{array}$ & $\begin{array}{l}\text { Minority } \\
\text { Population (\%) } \mathbf{d}\end{array}$ \\
\hline Alabama & 7.37 & 595 & 425.2 & 31.37 \\
Arizona & 4.34 & 509 & 501.4 & 40.94 \\
Arkansas & 2.82 & 485 & 551.6 & 24.02 \\
California & 1.09 & 475 & 532.5 & 57.25 \\
Colorado & 0.84 & 469 & 391.6 & 28.65 \\
Connecticut & 0.86 & 392 & 280.8 & 25.63 \\
Delaware & 7.54 & 488 & 681.6 & 31.25 \\
Florida & 9.01 & 509 & 712 & 39.18 \\
Georgia & 4.44 & 558 & 471 & 41.5 \\
Idaho & 1.75 & 480 & 247.2 & 14.4 \\
Illinois & 0.49 & 350 & 541 & 35.01 \\
Indiana & 0.57 & 411 & 314.8 & 16.46 \\
Iowa & 5.39 & 296 & 283.5 & 9.36 \\
Kansas & 1.37 & 318 & 425.0 & 19.3 \\
Kentucky & 5.97 & 462 & 263 & 12 \\
Louisiana & 2.96 & 846 & 697.8 & 37.72 \\
Maine & 0 & 151 & 115.5 & 4.54 \\
Maryland & 2.7 & 396 & 678.6 & 41.92 \\
Massachusetts & 0.2 & 243 & 447 & 20.27 \\
& & & &
\end{tabular}


Şahin, B., \& Şahin, İ. (2014). Factors of felon disfranchisement in the United States. International Journal of Human Sciences, 11(1), 778-793. doi: $10.14687 /$ ijhs.v11i1.2773

\begin{tabular}{|c|c|c|c|c|}
\hline Michigan & 0.66 & 511 & 562.4 & 22.42 \\
\hline Minnesota & 1.02 & 176 & 312 & 14.27 \\
\hline Mississippi & 6.89 & 658 & 298.6 & 41.11 \\
\hline Missouri & 2.18 & 514 & 545.6 & 17.67 \\
\hline Montana & 0.59 & 374 & 253.7 & 11.77 \\
\hline Nebraska & 4.77 & 237 & 281.8 & 15.45 \\
\hline Nevada & 2.63 & 503 & 741.6 & 42.03 \\
\hline New Hampshire & 0.26 & 207 & 138.7 & 6.64 \\
\hline New Jersey & 1.95 & 313 & 351.6 & 37.83 \\
\hline New Mexico & 1.32 & 323 & 643.2 & 57.66 \\
\hline New York & 0.83 & 326 & 434.9 & 39.71 \\
\hline North Carolina & 1.16 & 360 & 475.6 & 32.45 \\
\hline North Dakota & 0.3 & 214 & 127.9 & 10.05 \\
\hline Ohio & 0.53 & 428 & 350.3 & 17.29 \\
\hline Oklahoma & 1.88 & 664 & 497.4 & 28.18 \\
\hline Oregon & 0.52 & 367 & 280.3 & 19.52 \\
\hline Pennsylvania & 0.44 & 353 & 439.4 & 18.21 \\
\hline Rhode Island & 0.45 & 202 & 227.5 & 20.69 \\
\hline South Carolina & 1.55 & 525 & 765.5 & 34.71 \\
\hline South Dakota & 0.58 & 426 & 171.4 & 13.57 \\
\hline Tennessee & 2.12 & 423 & 760.2 & 22.75 \\
\hline Texas & 3.29 & 683 & 516.3 & 52.12 \\
\hline Utah & 0.37 & 246 & 224.4 & 17.69 \\
\hline Vermont & 0 & 262 & 136.6 & 4.713 \\
\hline Virginia & 6.76 & 314 & 282.2 & 32.74 \\
\hline Washington & 3.61 & 271 & 345.9 & 23.93 \\
\hline West Virginia & 0.76 & 314 & 279.7 & 6.36 \\
\hline Wisconsin & 1.51 & 393 & 284 & 14.6 \\
\hline Wyoming & 5.31 & 408 & 239.6 & 12.67 \\
\hline
\end{tabular}

Since some states have different disfranchisement policies, this study utilizes both the incarceration rate and violent crimes. Some states do not allow only the prison inmates to vote, while some others do not allow the ex-felons whether they are incapacitated or not. Including both of the variables as independent variables is likely to increase the chance of predicting the dependent variable of the study successfully.

\section{Discussion of Statistical Test Results}

Table 3 indicates the compared variables in terms of rates of violent crime, disfranchisement, incarceration and percentage of minority population of the states. The table combines five different single ANOVA test results and the F scores of those tests. US Census 
Şahin, B., \& Şahin, İ. (2014). Factors of felon disfranchisement in the United States. International Journal of Human Sciences, 11(1), 778-793. doi: $10.14687 /$ ijhs.v11i1.2773

Region groups ${ }^{3}$, US Census Division groups ${ }^{4}$, Lieske's 3-Fold political culture groups ${ }^{5}$, Lieske's 4Fold political culture groups ${ }^{6}$, Lieske's 5-Fold political culture groups ${ }^{7}$ and Elazar's political culture groups $^{8}$ were compared to each other in ANOVA tests in terms of different criminal justice variables including rate of disfranchisement.

Table 3 ANOVA (F Score) Results for Political Culture and Geographical Groups

\begin{tabular}{|c|c|c|c|c|c|c|}
\hline Groups & F (Regions) & F (Divisions) & $\begin{array}{l}\text { F (Elazar's } \\
\text { MIT) }\end{array}$ & $\begin{array}{l}\text { F (Lieske's 3- } \\
\text { Fold) }\end{array}$ & $\begin{array}{l}\text { F (Lieske's 4- } \\
\text { Fold) }\end{array}$ & $\begin{array}{l}\text { F (Lieske's } \\
\text { 5-Fold) }\end{array}$ \\
\hline Rate of disenfranchisement & $7.899 * * *$ & $3.872^{* * *}$ & $2.392^{*}$ & 1.954 & 1.649 & 1.522 \\
\hline Incarceration Rate & $9.641 * * *$ & $7.422 * * *$ & $3.65^{* * *}$ & $10.76^{* * *}$ & $7.239 * * *$ & $6.56^{* * *}$ \\
\hline Violent Crime Rate & $4.780^{* * *}$ & $2.462^{*}$ & $3.279 * * *$ & $4.59 * * *$ & $2.98^{* * *}$ & $2.775^{* * *}$ \\
\hline Minority Population & $4.232 *$ & $2.511^{*}$ & $2.367^{*}$ & $4.34 * * *$ & $5.6^{* * *}$ & $6.217^{* * *}$ \\
\hline $\begin{array}{l}\text { Political Culture Lieske 3- } \\
\text { Fold }\end{array}$ & $4.0572^{*}$ & $3.282^{* * *}$ & & & & \\
\hline $\begin{array}{l}\text { Political Culture Lieske 4- } \\
\text { Fold }\end{array}$ & $14.744 * * *$ & $7.479 * * *$ & & & & \\
\hline $\begin{array}{l}\text { Political Culture Lieske 5- } \\
\text { Fold }\end{array}$ & $4.735^{* * *}$ & $2.655^{*}$ & & & & \\
\hline Political Culture Elazar & $9.158^{* * *}$ & $4.421 * * *$ & & & & \\
\hline
\end{tabular}

US Census region and division groups have significant differences for the criminal justice variables utilized in the study. Geographical impact has the most significant differences for rate of disfranchisement and incarceration $(\mathrm{p}<0.01)$. Political culture groups also significantly vary among the geographical census regions and divisions. This is important evidence suggesting the relationship between geography and political culture. Even though the Lieske studies (1993, 2008) argue to provide more strong fundamentals than Elazar's findings that are less related to geography, Table 3 represents that geographical regions of the states are still influential in terms of political culture both in Lieske's and Elazar's scales .

Looking at the Table 1, it can be understood that the northeastern states are more individualistic and moralistic while the southern states are more traditionalistic in terms of Elazar's scale. Western and Midwestern states are more likely to be moralistic according to Table 1 . Table 3

\footnotetext{
3 1-North-East, 2-West, 3-South and 4-Midwest

4 1-New England, 2-Middle Atlantic, 3-East North Central, 4-West North Central, 5-South Atlantic, 6-East South Central, 7-West South Central, 8-Mountain, and 9-Pacific

${ }^{5}$ 1-Individualistic, 2-Individualistic-Moralistic, 3-Individualistic-Traditionalistic, 4-Moralistic, 5-Moralistic-Individualistic, 6-Traditionalistic, 7-Traditionalistic-Individualistic, and 8-Traditionalistic-Moralistic

6 1-Individualistic-Pluralistic, 2-Individualistic-Moralistic, 3-Moralistic, 4-Moralistic-, 5-Pluralistic, 6-PluralisticIndividualistic, 7-Pluralistic-Moralistic, 8-Pluralistic-Traditionalistic, 9-Traditionalistic, 10-Traditionalistic-Pluralistic, 11Traditionalistic-Moralistic

7 1-Bifurcated-Moralistic, 2-Bifurcated-Pluralistic, 3-Individualistic-Moralistic, 4-Individualistic-Pluralistic, 5-Moralistic, 6-Moralistic-Pluralistic, 7-Pluralistic-Bifurcated, 8-Pluralistic-Individualistic, 9-Pluralistic-Moralistic, 10-PluralisticSeparatist, 11-Separatist, 12-Pluralistic

8 1- Individualistic, 2-Individualistic Moralistic, 3-Moralistic, 4-Moralistic Individualistic, 5-Traditionalistic, 6Traditionalistic Individualistic, 7-Traditionalistic Moralistic
} 
Şahin, B., \& Şahin, İ. (2014). Factors of felon disfranchisement in the United States. International Journal of Human Sciences, 11(1), 778-793. doi: $10.14687 /$ ijhs.v11i1.2773

indicates that Elazar's scale of political culture groups the states significantly. In other words, Elazar's scale forms meaningful (statistically significant) differences among the states. Criminal justice variables also vary significantly among the political culture groups. All the criminal justice variables used in the study are varied statistically among the Elazar's groups. None of the Lieski's scale is as much successful as Elazar's scale in terms of explaining the group differences based on selected criminal justice variables.

Lieske's political culture scales could not form meaningful groups to show differences in terms of rate of disfranchisement. The F scores of all Lieske groups for rate of disfranchisement in the states are not statistically significant. Although the groups show a meaningful difference for minority, incarceration and violent crime rate, they fail to indicate the same difference for the dependent variable of this study. Success of Elazar's political culture groups over Lieske's scales in ANOVA tests may give an idea how Elazar's scales still have superiority in state and local government literature.

One should notice that ANOVA tests cannot report the direction or magnitude of the relationships between correlated variables. The test just shows that the political culture groups Elazar formed have statistically significant differences in terms of disfranchisement, incarceration, violent crime and minority percentage rate while Lieske's scales are as much successful as with all those variables but rate of disfranchisement. Therefore, a regression analysis was used to understand which variable has the greatest impact on disfranchisement rate. Three different regression analyses were done with SPSS software in which the variables were added in the regression models in addition to the others. Firstly, the political culture group variables were entered to the analysis, later the geographical regions and divisions were utilized and lastly the criminal justice variables were added to the analysis to understand actual effects of each individual variable.

Table 4 indicates that the $\mathrm{R}$ Square values for three regression analysis are .318, .332 and .354 respectively. It means that the independent variables used in the tests explained more than 30 percent of the variation in the disfranchisement rates in the states. Adjusted R Square values are relatively less than $\mathrm{R}$ Square values, which are .254, .234, .201 respectively. The lowest estimation percentage is nearly 20 per cent in the last test according to Adjusted R Square values. While R Square value attempts to explain the change in the dependent variable, there is a statistical danger in adding more independent variables; it can basically increase the explanation power of $\mathrm{R}$ Square unfairly. Adjusted R Square prevents this danger and gives more solid explanation scores in contrast to R Square. The lowest value for R Square in the first test is nearly 32 per cent, and the lowest Adjusted R Square value is .201 (20 per cent) for the third test. The results indicate that the 
Şahin, B., \& Şahin, İ. (2014). Factors of felon disfranchisement in the United States. International Journal of Human Sciences, 11(1), 778-793. doi: $10.14687 /$ ijhs.v11i1.2773

variables selected as independent can predict at least 20 per cent of the variation in disfranchisement rate. This is a big estimation score for a social study; however, it is not possible to know the individual effects of independent variables on the dependent from Table 4. Table 6 represents individual effect data.

Table 4 Model Summary

\begin{tabular}{|c|c|c|c|c|}
\hline Model & $\mathbf{R}$ & R Square & $\begin{array}{l}\text { Adjusted R } \\
\text { Square }\end{array}$ & $\begin{array}{l}\text { Std. Error of the } \\
\text { Estimate }\end{array}$ \\
\hline 1 & $.564^{a}$ & .318 & .254 & 2.03538 \\
\hline 2 & $.576^{\mathrm{b}}$ & .332 & .234 & 2.06251 \\
\hline 3 & $.595^{c}$ & .354 & .201 & 2.10687 \\
\hline \multicolumn{5}{|c|}{$\begin{array}{l}\text { a. Predictors: (Constant), Political Culture Lieske 5-Fold, Political Culture Lieske 4-Fold, Politica } \\
\text { Culture Elazar, Political Culture Lieske 3-Fold } \\
\text { b. Predictors: (Constant), Political Culture Lieske 5-Fold, Political Culture Lieske 4-Fold, } \\
\text { Political Culture Elazar, Political Culture Lieske 3-Fold, US Division, US Region } \\
\text { c. Predictors: (Constant), Political Culture Lieske 5-Fold, Political Culture Lieske 4-Fold, } \\
\text { Political Culture Elazar, Political Culture Lieske 3-Fold, US Division, US Region, Violent Crime } \\
\text { Rate, Incarceration Rate, Minority Population } \\
\text { d. Dependent Variable: Rate of disenfranchisement }\end{array}$} \\
\hline
\end{tabular}

ANOVA results of regression analysis for predicting disfranchisement rates are shown in the Table 5. There are three different regression analyses as discussed above, and all ANOVA results for those tests are statistically significant. The model fit for the first test is significant at 0.01 level. Since there are only four predictors, the first test is the most statistically significant one. Adding more variables into the regression analysis increased the chance of accepting null hypothesis in the following tests but it failed to do so (Table 5). The individual effects of the variables are examined in Table 6. The only statistically significant effect on the rate of disfranchisement was from the Lieske's 3-Fold and Lieske's 4-Fold political culture variables in all three tests. Lieske's 5-Fold test, Elazar's scale, other criminal justice variables and U.S. regions and divisions failed to predict the rate of disfranchisement statistically.

Table 5 ANOVA (F Score) Results of Regression Analysis

\begin{tabular}{|c|c|c|c|c|c|c|}
\hline Model & & Sum of Squares & df & Mean Square & $\mathbf{F}$ & Sig. \\
\hline \multirow[t]{3}{*}{1} & Regression & 83.036 & 4 & 20.759 & $5.011 * * *$ & $.002^{\mathrm{a}}$ \\
\hline & Residual & 178.139 & 43 & 4.143 & & \\
\hline & Total & 261.175 & 47 & & & \\
\hline \multirow[t]{3}{*}{2} & Regression & 87.429 & 7 & 12.490 & $2.875^{*}$ & $.016^{\mathrm{b}}$ \\
\hline & Residual & 173.746 & 40 & 4.344 & & \\
\hline & Total & 261.175 & 47 & & & \\
\hline \multirow[t]{3}{*}{3} & Regression & 92.497 & 9 & 10.277 & $2.315^{*}$ & $.035^{\mathrm{c}}$ \\
\hline & Residual & 168.678 & 38 & 4.439 & & \\
\hline & Total & 261.175 & 47 & & & \\
\hline \multicolumn{7}{|c|}{$\begin{array}{l}\text { a. Predictors: (Constant), Political Culture Lieske 5-Fold, Political Culture Lieske 4-Fold, Political Culture Elazar, Political } \\
\text { Culture Lieske 3-Fold } \\
\text { b. Predictors: (Constant), Political Culture Lieske 5-Fold, Political Culture Lieske 4-Fold, Political Culture Elazar, Political } \\
\text { Culture Lieske 3-Fold, Violent Crime Rate, Incarceration Rate, Minority Population } \\
\text { c. Predictors: (Constant), Political Culture Lieske 5-Fold, Political Culture Lieske 4-Fold, Political Culture Elazar, Political } \\
\text { Culture Lieske 3-Fold, Violent Crime Rate, Incarceration Rate, Minority Population, US Division, US Region } \\
\text { d. Dependent Variable: Rate of disenfranchisement } \\
* * * p<0.01 \\
* p>0.01 \text { and }<0.05\end{array}$} \\
\hline
\end{tabular}


Şahin, B., \& Şahin, İ. (2014). Factors of felon disfranchisement in the United States. International Journal of Human Sciences, 11(1), 778-793. doi: $10.14687 /$ ijhs.v11i1.2773

The first assumption that geographical differences have effect on disfranchisement rate is proven to be wrong since both of the census variables do not have a significant Beta score in the regression test (Table 6). It brings to mind that the census regions and divisions are not reflecting meaningful differences even though political cultures are. The ANOVA test in Table 3 indicates statistical differences among the political culture groups in terms of geographical regions; however, it failed to predict the dependent variable of the study as much successfully as Lieske's political variables did. If the census divisions are formed with help of political culture studies, they may need an update with more state and local government research.

Table 6 Coefficients of Regression Analysis

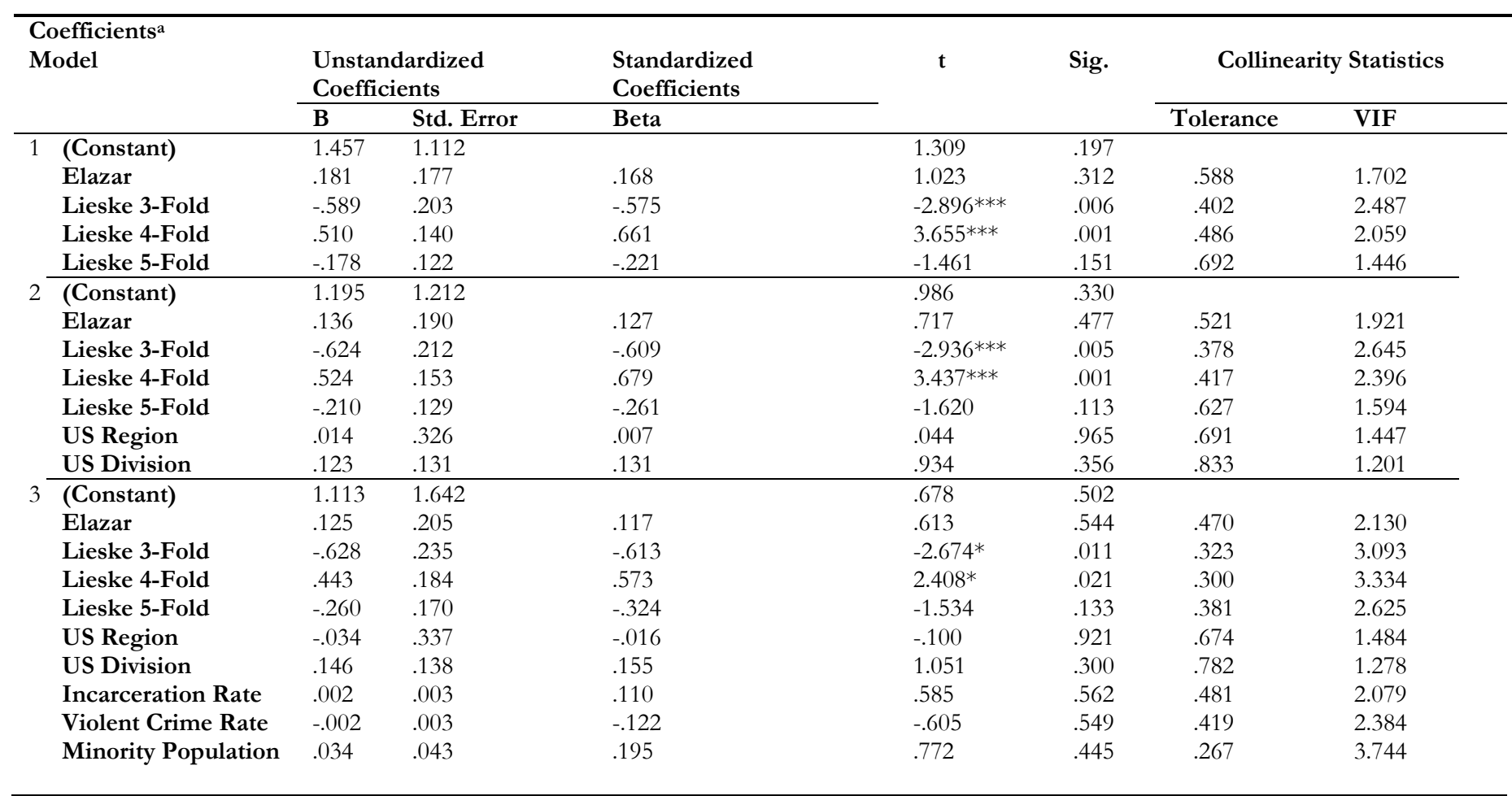

a. Dependent Variable: Rate of disenfranchisement

b. $\quad * * * \mathrm{p}<0.01$

c. $\quad * \mathrm{p}>0.01$ and $<0.05$

Second assumption's variables, the number of ex-felons and prison inmates in a state and number of violent crimes are not found to be related to the number of people that are not allowed to vote. It is surprising to see that these variables are not correlated since the state legislations regulating disfranchisement generally target inmate or ex-felon populations in states. The second assumption of this study was that the criminal justice system processes are less important than those of political bias in the states in terms of disfranchisement laws. Non-correlated criminal justice variables and rate of disfranchisement figures prove that the second assumption is true. In other words, political climate of a region is likely to affect disfranchisement of people more than criminal justice facts. 
Şahin, B., \& Şahin, İ. (2014). Factors of felon disfranchisement in the United States. International Journal of Human Sciences, 11(1), 778-793. doi: $10.14687 /$ ijhs.v11i1.2773

It is argued in the second assumption that the traditionalistic states have higher disfranchisement rates. Lieske's 3 and 4 fold political culture scales indicate that top two political culture groups are TI (for 3-Fold) and TP (for 4-Fold). TI (Traditionalistic-Individualistic) group was formed by Alabama, Arkansas, Georgia, Mississippi, North Carolina, South Carolina and Tennessee. TP (Traditionalistic-Pluralistic) group included nearly the same states; Alabama, Arkansas, Georgia, Kentucky, Mississippi, North Carolina, South Carolina, and Tennessee. This shows traditionalistic southern states have a higher rate of disfranchisement than other states, which allow us to accept second assumption.

Percentage of minority population in a state is the other variable that is not correlated with the rate of disfranchisement. Elazar (1984) argues that this variable has an important impact on political culture, and therefore public policies. However, in terms of the dependent variable of this study, the disfranchisement rate is not correlated with the minority diversity. To sum up, the population of minorities in a state does not change the rate of disfranchisement.

The statistically significant difference among the means of Elazar's and Lieske's 5-Fold political culture groups and different census regions and divisions did not make a statistically significant impact on rate of disfranchisement in the regression analysis. However, the statistical results for two Lieske scales (3-Fold and 4-Fold) in all three tests indicate that the assumption of political culture impact on disfranchisement is supported. Elazar's political culture groups do not have a statistical effect in the regression analysis because it may be outdated. Lieske (2008) criticizes Elazar's scale for different reasons as mentioned above, and the study findings proved that Lieske's political culture groups are more successful to predict the selected criminal justice variable. Therefore, the third assumption of the study is supported by the study results.

When it is thought that the political culture attributes of the states was created as a scale in 1984, the second possibility is more likely to be adopted. All the criminal justice variables including the disfranchisement rate were obtained for the years after 2006. In twenty years after 1984, there have been many social, demographic, economic and political changes in the U.S. This may be the reason why regression test find out Lieske's political culture scales more successful than that of Elazar's'.

\section{Limitations}

The most important limitation of the study is the multicollinearity problem. This problem occurs when highly correlated variables are utilized as independent variables of a dependent variable in a regression analysis. The tests are firstly grouped the variables as the literature suggests to avoid multicollinearity. There are three different regression tests in the study (Table 6). Moreover, SPSS software was used too generate VIF (Variance Inflation Factors) and tolerance 
scores. These scores are used to estimate the multicollinearity in a regression analysis. VIF is accepted to be less than 5 (or 10) to allow the researcher assuming no multicollinearity in the regression analysis (Craney $\&$ Surles, 2002).

Tolerance score is another tool that SPSS software offers in the regression analysis, which provides another figure to explain multicollinearity in the statistical tests. O'brien (2007) suggests that tolerance scores that are too close to 0 can mean a problem of multicollinearity. Table 6 controls both VIF and tolerance of the regression tests for each variable. The smallest value for tolerance in all three tests is .267 and the greatest VIF score in all three tests is 3.744 . These numbers are way far away from the multicullinearity limit the literature suggests.

However, the sample size of the test can be criticized since the adjacent states have a limited number of forty eight. Literature suggests the regression test should utilize 10 or more observations per indicator (Concato et al., 1993). Three regression tests in the study utilized four, six and nine independent variables respectively. Therefore, the study should have utilized sixty and ninety observations for the second and third regression analysis. The future studies should limit the variables or group them since the number of states will stay steady.

\section{Conclusion and Contributions}

There is no doubt that participating in election process is the very basic right for the citizens living in democratic society regardless of their background, race, and socio-economic status. It seems that the debates on felon disfranchisement will increasingly continue as long as the states disfranchise a large number of citizens from election process because of their felony convictions. There is no unity among the state policies in terms of felon disfranchisement. By utilizing the interdisciplinary perspective and examining the other state characteristics, future studies need to focus on this differentiation to identify the motivation behind their policy choices and to better understand why state policies on this issue differentiate.

Elazar's (1984) scale for traditionalistic, moralistic, and individualistic states needs to be revised. The states developed different characters in recent decades, which the literature failed to address yet. More research should be focused on the regional and state differences in terms of socio-economical variables and other public policy variables as discussed in this study. Only in this way can we understand the causes and effects of harmful and useful public policies in the U.S. 
Şahin, B., \& Şahin, İ. (2014). Factors of felon disfranchisement in the United States. International Journal of Human Sciences, 11(1), 778-793. doi: $10.14687 /$ ijhs.v11i1.2773

\section{References}

Ausburg, T. (2006). Becoming Interdisciplinary: An Introduction to Interdisciplinary Studies. 2nd edition. New York:

Kendall/Hunt Publishing.

Behrens, A. (2004). Voting-Not Quite a Fundamental Right? A Look at Legal and Legislative Challenges to Felon Disfranchisement Laws. Minnesota Law Review, 89 (4): 231-275.

Behrens, A., Uggen, C., and Manza, J. (2003). Ballot Manipulation and the "Menace of Negro Domination": Racial Threat and Felon Disenfranchisement in the United States, 1850-2000. American Journal Of Sociology, 109: 559-605.

Concato, J., Feinstein A.R., and Holford, T.R. (1993). The risk of determining risk with multivariable models. Annals of Internal Medicine, 118(3): 201-211.

Corzine, J., Creech, J., and Corzine, L. (1983). Black Concentration and Lynchings in the South: Testing Blalock's Power- Threat Hypothesis. Social Forces, 61 (3): 774-796.

Craney, T. A. and Surles, J.G.(2002) Model-Dependent Variance Inflation Factor Cutoff Values, Quality Engineering. 14(3): 391-403.

Elazar, D. J. (1974). Land Space and Civil Society in America. The Western Historical Quarterly, 5 (3): 261-284.

Elazar, D. J. (1984). American Federalism: A View from the States. New York: Harper and Row as cited in Hero and Tolbert (1996).

Engstrom, R. L. (1994). The Voting Rights Act: Disfranchisement, Dilution, and Alternative Election Systems. Political Science and Politics, 27 (4): 685-688.

Hero, R. E., and Tolbert, C. J. (1996). U.S., A Racial/Ethnic Diversity Interpretation of Politics and Policy in the States of the. American Journal of Political Science, 40 (3): 851-871.

James, D. R. (1988). The Transformation of the Southern Racial State: Class and Race Determinants of Local-State Structures. American Sociological Review, 53 (2): 191-208.

James, J. B. (1956). Southern Reaction to the Proposal of the Fourteenth Amendment. The Journal of Southern History, 22 (4): 477-497.

Keyssar, A. (2000). The Right to Vote: The Contested History of Democracy in the United States. New York, NY: Basic Books.

Levitas, D., and Cox, J. (2008). State and Regional Trends in Voting Policy and Barriers to Civic Participation in Six Southern States 2006 and 2007. Atlanta, GA: Southern Regional Council.

Manza, J., and Uggen, C. (2006). Locked Out: Felon Disenfranchisement and American Democracy. New York, NY: Oxford University Press.

McMillan, $\quad$ M. (1955). Constitutional Development in Alabama, 1798-1901. Chapel Hill: University of North Carolina Press as cited in Behrens, Uggen, \& Manza, 2003.

O’brien, R.M. (2007) A Caution Regarding Rules of Thumb for Variance Inflation Factors. Quality \& Quantity, 41(5): 673.

Perman, M. (2001). Struggle for Mastery: Disfranchisement in the South, 1888-1908. Chapel Hill, NC: University of North Carolina Press.

Raskin, J. B. (2001). A Right to Vote: Amazingly, the Constitution fails to guarantee the most basic of Democratic rights. The American Prospect Magazine, August 2001. Retrieved on January 13, 2009 from http://www.thirdworldtraveler.com/Democracy/A Right to Vote.html

Russ, W. A. (1934). The Negro and White Disfranchisement During Radical Reconstruction. The Journal of Negro History, 19 (2): 171-192.

The Sentencing Project (2008). Statistics by State. Retrieved on September 15, 2008, from Disfranchsement Rate: http://www.sentencingproject.org/StatsByState.aspx

USDOJ(a) (U.S Department of Justice) (2008). Retrieved on September 15, 2008, from Crime in the United States: http://www.fbi.gov/ucr/cius2006/data/table_05.html

USDOJ(b) (U.S Department of Justice) (2008). Retrieved on September 15, 2008, from Prisoners in 2006: http://www.ojp.usdoj.gov/bjs/pub/pdf/p06.pdf

Wasserman, I. M. (1977). Southern Violence and the Political Process. American Sociological Review, 42 (2): 359362.

Zeisel, H. (1981). Race Bias in the Administration of the Death Penalty: The Florida Experience. Harvard Law Review, 95 (2): 456-468. 